\title{
Study of the use of analgesics by patients with headache at a specialized outpatient clinic (ACEF)
}

\author{
Estudo do uso de analgésicos em pacientes com cefaleia em um ambulatório \\ especializado (ACEF) \\ Olga Francis Pita Chagas', Fabiola Dach Éckeli², Marcelo E. Bigal ${ }^{3}$, Mayko Olinto Amaral da Silva4, Jose \\ Geraldo Speciali
}

\begin{abstract}
Objective: To evaluate the use of analgesics in headache diagnosed in Outpatients Headache Clinic (ACEF), as well as his involvement in the activities of the patients. Method: 145 patients with headache seen at ACEF during the period August/July 2009/2010 underwent a questionnaire and interview with neurologist responsible for the final diagnosis according to ICHD-II. Results: Relationship Women:Men 7:1. 1) Prevalence: Migraine without aura (52.4\%), migraine with aura (12.4\%), chronic migraine (15.2\%) and medication overuse headache $(\mathrm{MOH})(20 \%)$. 2) Analgesic drugs used: Compounds with Dipyrone (37\%), Dipyrone (23\%), Paracetamol (16\%) compound with Paracetamol $(6 \%)$, triptans $(6 \%)$ and non steroidal anti-inflammatory drugs (12\%). There was a significant decrease in the duration of pain and less interference in the activities of the headache patients after the use of analgesics. Conclusion: Prevalence of $\mathrm{MOH}$ has been increasing in population level and specialized services. New studies emphasizing the $\mathrm{MOH}$ are needed to assist in the improvement of their diagnostic and therapeutic approach.
\end{abstract}

Keywords: headache, analgesics, medication overuse headache, epidemiology.

RESUMO

Objetivo: Avaliar a utilização de analgésicos nas cefaleias diagnosticadas no Ambulatório de Cefaleias (ACEF), bem como a sua intervenção nas atividades dos pacientes. Método: 145 pacientes com cefaleia atendidos no ACEF durante o período entre Agosto/2009 a Julho/2010 foram submetidos a um questionário e à entrevista com médico neurologista responsável pelo diagnóstico final, segundo a ICHD-II. Resultados: Relação Mulheres:Homens de 7:1. 1) Prevalência: Migrânea sem aura (52,4\%), migrânea com aura (12,4\%), migrânea crônica (15,2\%) e CEM (20\%). 2) Analgésicos utilizados: Compostos com Dipirona (37\%), Dipirona (23\%), Paracetamol (16\%), compostos com Paracetamol (6\%), triptanos (6\%) e drogas antiinflamatórias esteroidais (12\%). Houve uma diminuição significativa da duração da dor e menor interferência da cefaleia nas atividades dos pacientes após o uso dos analgésicos. Conclusão: Prevalência da cefaleia por uso excessivo de medicamento (CEM) vem aumentando em nível populacional e em serviços especializados. Novos estudos enfatizando a CEM são necessários para auxiliar na melhora da sua abordagem diagnóstica e terapêutica.

Palavras-chave: cefaleia, analgésicos, cefaleia por uso excessivo de medicamento, epidemiologia.

Headache is one of the most frequent complaints in clinical practice and one of the major reasons for care in specialized health services ${ }^{1}$.

According to the 2nd Edition of the International Classification of Headache Disorders (ICHD-II), migraine is a recurrent and disabling primary headache which occupies $19^{\text {th }}$ position in the ranking of the $\mathrm{WHO}$ among incapacitating diseases $^{2}$. Normally it manifests as headache attacks of moderate or strong intensity lasting four to 72 hours and frequently associated with nausea, vomiting, photophobia, and phonophobia 2 .

Because of their peculiar characteristics, in addition to being aggressively advertised by laboratories through the media $^{3,4}$, analgesics have started to be used in an abusive manner by many patients, representing one of the main causes of migraine chronicity and the consequent onset of medication overuse headache $(\mathrm{MOH})^{5,6,7}$.

\footnotetext{
Universidade de Ribeirão Preto, Ribeirao Preto SP, Brazil;

${ }^{2}$ Universidade de São Paulo, Faculdade de Medicina de Ribeirão Preto, Divisão de Neurologia, Departamento de Neurociências e Ciência Comportamental, Ribeirao Preto SP, Brazil;

${ }^{3}$ Migraine \& Headache Clinical Development, Global Branded R\&D, Teva Pharmaceuticals;

${ }^{4}$ Faculdade de Medicina, Hospital das Clínicas, Ribeirao Preto SP, Brazil.

Correspondence: Jose Geraldo Speciali; Departamento de Neurociências e Ciências do Comportamento, Hospital das Clínicas da FMRP-USP; Av. Bandeirantes, 3900/4 andar; 14049-900 Ribeirão Preto SP, Brasil; Email: josespeciali@yahoo.com.br

Conflict of interest: There is no conflict of interest to declare.

Received 21 January 2015; Received in final form 13 February 2015; Accepted 04 March 2015
} 
The world market of analgesics grew by $27 \%$ from 2006 to $2010^{3,8}$. In Brazil, in 2010 this segment involved US\$ 902 millions on the analgesic market, a figure that placed the country on a leading level among emergent nations, representing the sixth largest market in the world ${ }^{3,8}$. In view of this potential demand, more than 380 analgesic products have been registered on the Brazilian market between 2011 and 2012, with the following products being those most frequently sold (in millions of $\mathrm{R} \$$ ): $1^{\text {st }}$, Dorflex ${ }^{\oplus}$ (299.97); $2^{\text {nd }}$, Neosaldina ${ }^{\circ}$ (204.40); $3^{\text {rd }}$, Buscopan ${ }^{\circ}$ compound (111.98); $5^{\text {th }}$ Tylenol $^{\bullet}(106.38)$; and $6^{\text {th }}$, Benegrip ${ }^{\bullet}(105.21)^{3,8}$.

Among the analgesics most frequently cited and specifically used for headache were: $1^{\text {st }}$, Dipyrone; $2^{\text {nd }}$, Paracetamol; $3^{\text {rd }}$, Aspirin; $4^{\text {th }}$, Ibuprofen; and $5^{\text {th }}$, opioid derivatives (Codeine, Tramadol $)^{9}$; indicating the possibility that these are the medications most frequently involved in the development of $\mathrm{MOH}$, although to date no studies have confirmed this possibility ${ }^{9,10}$.

The Headache and Craniofacial Pain Service of the University Hospital, Faculty of Medicine of Ribeirão Preto (ACEF in the Portuguese acronym) is a tertiary level outpatient clinic specialized in the care for patients with headache. Its target public includes patients who have already received care in other services of lesser complexity with unsatisfactory results in the management of the painful syndrome. The great majority of patients referred to the ACEF have chonic headache and a significnat part of them indavertently and excessively uses medications for symptomatic relief.

On the basis of the above considerations, the objective of the present study was to evaluate the use of analgesics for the types of headache diagnosed at the ACEF, as well as the interference of these medications with the activities of the patients.

\section{METHOD}

A total of 145 patients with headache of both sexes, aged 18 to 80 years and seen at ACEF (Outpatients Headache Clinics) were studied in a prospective and sequential manner from August 2009 to July 30, 2010.

Data were collected by means of an interview and the responses to a semi-structured questionnaire especially elaborated for this investigation containing demographic data (age, sex, race, marital status), characteristics of the headache experienced during the last month (intensity, duration, frequency, interference with activities), and information about the analgesics used (type, frequency and time of use, quantity, efficacy).

The type of headache presented by the patients was diagnosed by a neurologist according to the ICHD-II' ${ }^{2}$, since during the study period the ICHD-III beta, a recent classification published in 2013, had not yet been elaborated. On this basis, daily headaches with the concomitant abuse of analgesics were classified as $\mathrm{MOH}$. In the present study, $\mathrm{MOH}$ was subdivided into a condition with a history of migraine and a condition with a history of tension type headache. Exclusion criteria were: age outside the preestablished range, refusal to respond to the questionnaire and/or to participate in the study, and inability to respond to the questionnaire due to physical, psychiatric and/or cognitive disorders.

There were discrepancies between the information provided by the patient and the definitive diagnosis made by the doctor since some patient did not characterize their headache in an appropriate manner in response to the questionnaire applied. For this reason, we opted to consider the definitive diagnosis made by the neurologist responsible for patient care, a fact that, in our opinion, explains the discrepant data related to the prevalence of headache and its interference with the activities of the patients.

The study was approved by the Research Ethics Committee of the University Hospital, Faculty of Medicine of Ribeirão Preto, University of São Paulo (HCFMRP-USP), protocol no. 9240/2009, and all patients gave written informed consent to participate.

The data obtained with the questionnaire were converted to tables and figures prepared with the Microsoft Excel 2010 software and submitted to statistical analysis.

This study was financed by São Paulo Research Foundation (FAPESP) for a year under process no. 2012/20695-0.

\section{RESULTS}

Of the 145 patients evaluated, 127 (87.6\%) were females and $18(12.4 \%)$ were males, corresponding to a $7: 1$ female:male ratio. Most were white (57.2\%) and married (51.7\%), ranging in age from 18 to 78 years.

Table 1 shows the distribution of the patients according to the diagnosis of headache.

Migraine without aura affected the largest number of cases in both sexes (67 women representing $52.75 \%$ of the female cases and 9 men representing $50 \%$ of the male cases), followed by $\mathrm{MOH}$ (24 women representing $18.9 \%$ of the female cases and 5 men representing $27.8 \%$ of the male cases). The remaining diagnostic distributions according to sex are illustrated in Figure 1.

Table 1. Case distribution according to diagnosis*.

\begin{tabular}{lcc}
\hline Diagnosis & Cases $(\mathrm{n})$ & $\%$ \\
\hline Migraine with aura & 18 & 12.4 \\
Chronic migraine & 22 & 15.2 \\
MOH & 29 & 20 \\
$\quad$ Migraine without aura & 25 & 17.2 \\
Migraine with aura & 2 & 1.4 \\
TTH & 2 & 1.4 \\
Migraine without aura & 76 & 52.4 \\
Total & 145 & 100 \\
\hline
\end{tabular}

MOH: Medication overuse headache; TTH:Tension type headache.

*There was discrepancy between the information given by the patient and the medical diagnosis. The results presented were based on the definitive diagnosis made by the neurologist responsible for patient care. 
Among the analgesics most frequently reported for the acute treatment of headache, Dipyrone compounds occupied first place (37\% of cases), followed by Dipyrone $(23 \%)$ and Paracetamol (16\%), as shown in Table 2.

Table 3 shows the distribution of the analgesics used according to the type of headache reported. The number of analgesics used $(n=250)$ exceeded the number of individuals evaluated $(n=145)$ since some subjects used more than one type of analgesic and some took more than one pill per day of pain.

Sixty-three percent of the patients reported that they chose a given type of analgesic because of its effectiveness, whereas a minority of patients (11\%) used an analgesic only because it was supplied to them by the health care clinic. In addition, $57 \%$ of the patients interviewed reported that they

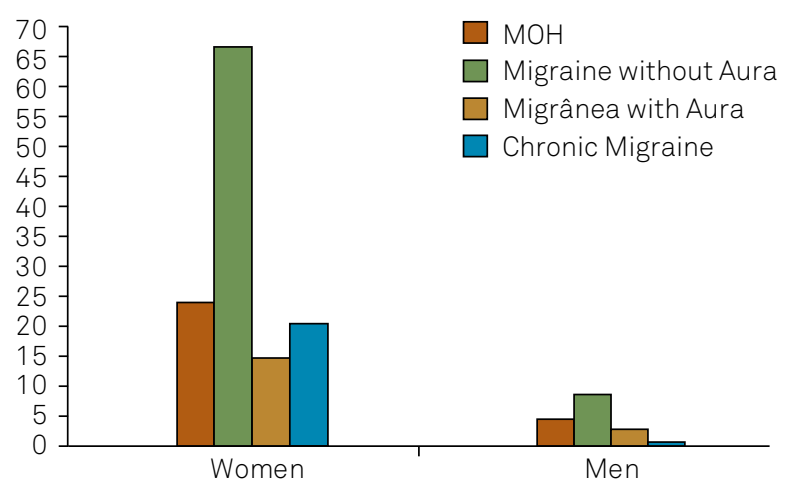

$\mathrm{MOH}$ : medication overuse headache.

Figure 1. Distribution of the diagnosis according to sex, based on the number of cases.

Table 2. Analgesics most frequently used for the acute treatment of headaches, as percentage.

\begin{tabular}{lcc}
\hline Analgesic & Frequency $(\mathrm{n})$ & $\%$ \\
\hline Paracetamol compounds & 15 & 6 \\
Triptans & 16 & 6.4 \\
NSAID & 30 & 12 \\
Paracetamol & 39 & 15.6 \\
Dipyrone & 57 & 22.8 \\
Dypirone compounds & 93 & 37.2 \\
Total & 250 & 100 \\
\hline
\end{tabular}

NSAID: Nonsteroidal Anti-Inflammatory Drugs. purchased medications at drugstores, while only $1 \%$ obtained them from friends and neighbors. About 55\% of the patients used analgesics prescribed by the doctor, whereas $34 \%$ performed self-medication.

Figure 2 illustrates the period during which the analgesics were used by the patients $(n=145)$. It can be seen that most patients used these medications at the onset of pain $(n=64$; $44.14 \%)$ or in the presence of strong pain $(n=64 ; 44.14 \%)$.

Figures 3 and 4 illustrate the duration of pain without $(n=141)$ and with $(n=143)$ the use of the analgesics, which was significantly reduced with the use of the medication.

Regarding the impact of headache on the patients, Tables 4 and 5 respectively demonstrate in a comparative manner graded from 1 to 10 the interference of pain with their work and leisure activities, according to the utilization or not of an analgesic, revealing an increase in the number of patients attributing a low score to the interference of headache with their activities after the use of medication.

\section{DISCUSSION}

$\mathrm{MOH}$ can be defined as a secondary headache occurring 15 days or more per month over a period of at least three months, as a consequence of the excessive and chronic consumption of one or more medications for symptomatic relief. ${ }^{2}$ This type of headache usually ceases after the interruption of excessive use of medication ${ }^{2}$.

$\mathrm{MOH}$ is considered to be the third most frequent type of headache in the world population ${ }^{11,12}$, with a prevalence of about 1 to $1.4 \%$, and predominating among women in the 50 year age range ${ }^{13,14}$. However, this percentage is increasing, especially in North America, Europe and Asia ${ }^{15}$.

In the present study, the prevalence of $\mathrm{MOH}$ among women, in addition to confirming known data ${ }^{16,17,18,19}$, supports the notion that the larger female series is due to the fact that women seek health care more frequently than men ${ }^{16,17}$. In addition, since the study was conducted at a specialized outpatient clinic, the larger number of female patients indicates that pain is more disabling among women, as also demonstrated in other studies ${ }^{20,21}$.

Regarding the diagnoses detected, migraine without aura affected a larger number of subjects (52.4\%) of both sexes, followed

Table 3. Analgesics most frequently used for the acute treatment of headache according to diagnosis.

\begin{tabular}{lccccc}
\hline \multicolumn{1}{c}{ Analgesics/diagnosis } & Migraine with aura & Chronic migraine & MOH & Migraine without aura & Total N (\%) \\
\hline Paracetamol compounds & 1 & 4 & 4 & 6 & $15(6)$ \\
Triptans & 5 & 1 & 4 & 6 & $16(6)$ \\
NSAID & 3 & 1 & 18 & 19 & $30(12)$ \\
Paracetamol & 2 & 5 & 13 & 27 & $39(16)$ \\
Dipyrone & 6 & 11 & 28 & 39 & $93(23)$ \\
Dipyrone compounds & 8 & 18 & 70 & 115 & $250(100)$ \\
Total & 25 & 40 &
\end{tabular}

$\mathrm{MOH}$ : Medication overuse headache; NSAID: nonsteroidal anti-inflammatory drugs. 


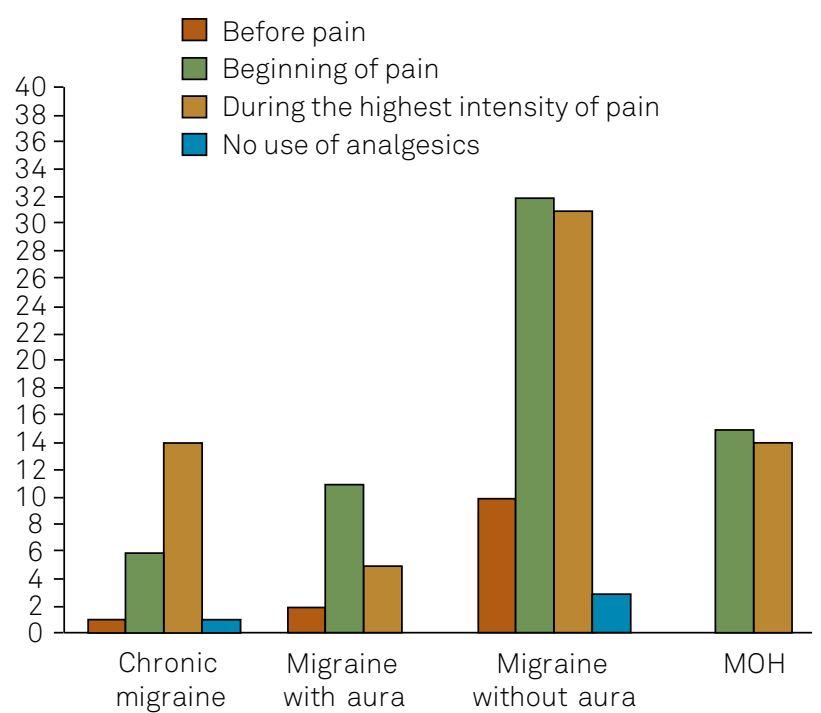

$\mathrm{MOH}$ : medication overuse headache.

Figure 2. Time of pain when the use of an analgesic occurs according to type of headache, based on the number of cases.

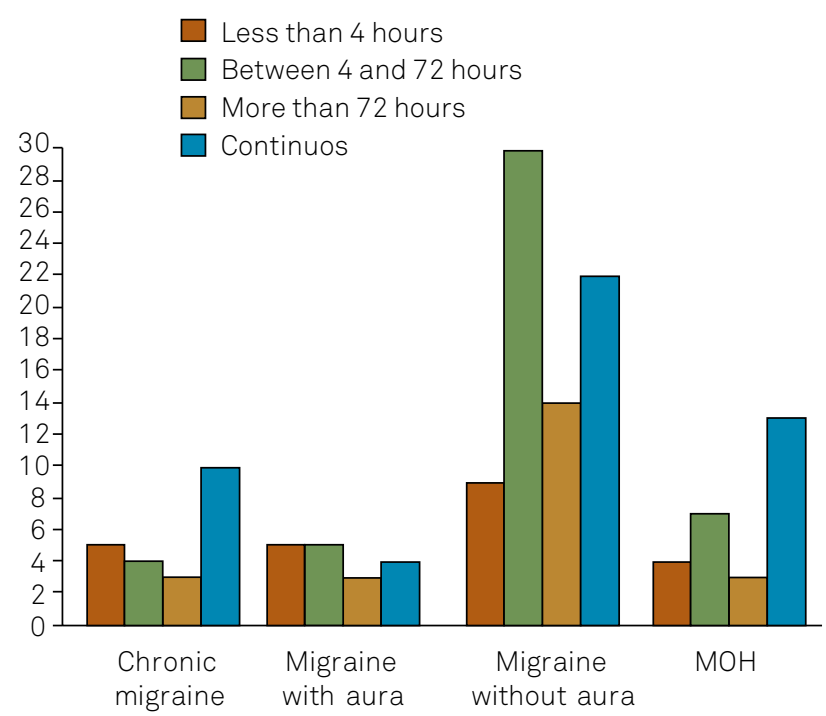

$\mathrm{MOH}$ : medication overuse headache.

Figure 3. Relationship between the duration of pain and the lack of use of analgesics in the last month according to diagnosis, based on the number of cases.

by $\mathrm{MOH}(20 \%)$, with mean ages of 39.34 and 44.27 years, respectively; $89.29 \%$ of the cases of $\mathrm{MOH}$ were the result of excessive use of analgesics among patients with a history of migraine without aura. This result agrees with previous studies stating that migraine is the major headache among those that undergo transformation due to exaggerate analgesic consumption ${ }^{18,22}$.

In studies conducted at tertiary care units, migraine has been described as the most prevalent primary headache, with frequency rates of 30 to $80 \%^{16,18,23,24}$. A study conducted at the Headache Outpatient Clinic of the Federal University of Minas Gerais reported that $\mathrm{MOH}$ was the most frequent (16.6\%), with a percentage similar to that of the diagnosis of primary headaches ${ }^{18}$.

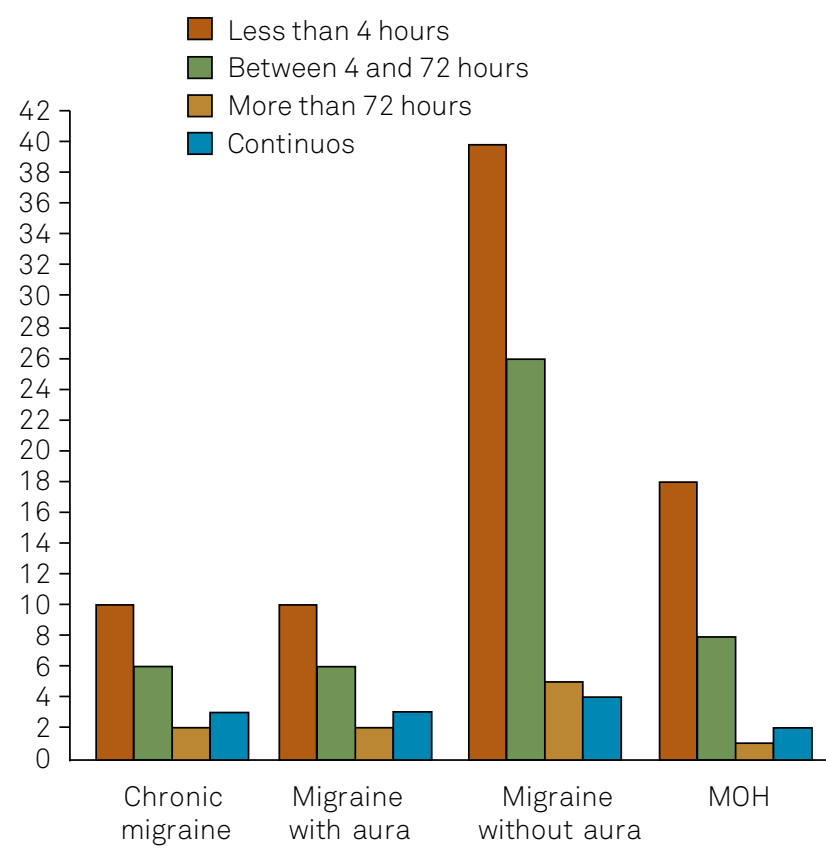

$\mathrm{MOH}$ : medication overuse headache.

Figure 4. Relationship between the duration of pain and the use of analgesics in the last month according to diagnosis, based on the number of cases.

Regarding tension type headache (TTH), the number of cases was not relevant enough to be included in the present study. Krymchantowski and Moreira Filho ${ }^{25}$ stated that TTH, even in its chronic form, is less frequent in medical clinics specializing in headache.

A retrospective study conducted on 3328 patients at a specialized outpatient clinic of Escola Paulista de Medicina reported that TTH was diagnosed in almost $23 \%$ of cases, reaching the position of second most prevalent hedache of the service ${ }^{16}$. Another study carried out at a specialized outpatient clinic in Navarra (Spain) detected a $20.5 \%$ prevalence of TTH cases, losing first position only to migraine when compared to other types of headaches described ${ }^{26}$. In the same study, $10.8 \%$ of secondary headaches were attributed to the abuse of medications.

A study conducted on 327 patients seen in a specialized clinic in Hungary detected a prevalence of TTH very close to that of migraine (31\%), demonstrating some discrepancies among world results.

Regarding the prevalence of headache types around the world, Stovner et al. ${ }^{23}$, in a population-based study that analyzed 107 publications from different countries, demonstrated that most countries have TTH as the most prevalent type of primary headache, affecting almost $42 \%$ of the adult world population.

The disproportion of the prevalence of the various types of headache in the general population compared to that obtained in specialized clinics reflects the greater or lesser morbidity that each headache causes to the individuals, influencing the demand for medical care. 
Table 4. Interference of headache with work activities reported in a comparative and gradual manner on a scale of 01 to 10 according to the use or not of analgesics.

\begin{tabular}{|c|c|c|c|c|c|c|c|c|}
\hline \multirow{3}{*}{$\begin{array}{l}\text { Activity } \\
\text { Analgesics } \\
\text { Score }\end{array}$} & \multicolumn{8}{|c|}{ Work } \\
\hline & \multicolumn{4}{|c|}{ Without use } & \multicolumn{4}{|c|}{ With use } \\
\hline & 01-02 (\%) & 03-08 (\%) & $09-10(\%)$ & Total (\%) & $01-02(\%)$ & $03-08(\%)$ & $09-10(\%)$ & Total (\%) \\
\hline $\mathrm{MOH}$ & $00(0)$ & $11(39.29)$ & $17(60.71)$ & $28(100)$ & $05(17.86)$ & $20(71.43)$ & $03(10.71)$ & $28(100)$ \\
\hline Migraine without aura & $02(2.67)$ & $28(37.33)$ & $45(60)$ & $75(100)$ & $19(26.39)$ & $45(62.5)$ & $08(11.11)$ & $72(100)$ \\
\hline Migraine with aura & $00(0)$ & 06 (33.33) & $12(66.67)$ & $18(100)$ & $05(29.41)$ & $11(64.71)$ & $01(5.88)$ & $17(100)$ \\
\hline Chronic migraine & $00(0)$ & $07(31.82)$ & $15(68.18)$ & $22(100)$ & $01(4.76)$ & $17(80.95)$ & $03(14.29)$ & $21(100)$ \\
\hline
\end{tabular}

$\mathrm{MOH}$ : Medication overuse headache.

Table 5. Interference of headache with leisure activities reported in a comparative and gradual manner on a scale of 01 to 10 according to the use or not of analgesics.

\begin{tabular}{|c|c|c|c|c|c|c|c|c|}
\hline \multirow{2}{*}{$\begin{array}{r}\text { Activity } \\
\text { Analgesics }\end{array}$} & \multicolumn{8}{|c|}{ Leisure } \\
\hline & \multicolumn{4}{|c|}{ Without use } & \multicolumn{4}{|c|}{ With use } \\
\hline Score & 01-02 (\%) & 03-08 (\%) & 09-10 (\%) & Total (\%) & 01-02 (\%) & $03-08(\%)$ & $09-10(\%)$ & Total (\%) \\
\hline $\mathrm{MOH}$ & $02(6.9)$ & $13(44.83)$ & $14(48.28)$ & $29(100)$ & $05(17.24)$ & $22(75.86)$ & $02(6.9)$ & $29(100)$ \\
\hline Migraine without aura & $01(1.32)$ & 25 (32.89) & 50 (65.79) & 76 (100) & $18(24.66)$ & $49(67.12)$ & $06(8.22)$ & $73(100)$ \\
\hline Migraine with aura & $00(0)$ & 06 (33.33) & $12(66.67)$ & $18(100)$ & $04(23.53)$ & $13(76.47)$ & $00(0)$ & $17(100)$ \\
\hline Chronic migraine & $00(0)$ & $11(50)$ & $11(50)$ & $22(100)$ & $02(9.52)$ & $17(80.95)$ & $02(9.52)$ & $21(100)$ \\
\hline
\end{tabular}

$\mathrm{MOH}$ : Medication overuse headache.

The present study showed that the prevalence of migraine without aura was very close for the two sexes. Sixty-seven $(52.76 \%)$ of a total of 127 women had this type of headache compared to 9 (50\%) of a total of 18 men, with a difference of only $2.76 \%$ more among women. In contrast, regarding $\mathrm{MOH}$, most patients (27.8\%) were men, compared to only 24 cases among women (18.9\% of all women), in contrast to current literature findings at the population level.

The higher incidence of $\mathrm{MOH}$ among the men of the present series leads us to believe that negligence in the treatment of headache on the part of men causes them to delay seeking treatment and to ingest a greater quantity of analgesics. As a consequence, men will be seen at a tertiary level hospital when they already have chronic daily headache due to abuse of medication. Thus, the number of male patients with $\mathrm{MOH}$ treated at tertiary level units increases compared to the population level.

Among the analgesics most frequently used for the acute treatment of pain, Dipyrone compounds occupied first place compared to all other medications in all the diagnoses made (37\% of all patients), including $\mathrm{MOH}$, with $40 \%$ of affected patients using this drug.

These results indicate that media influence may have been the cause of this important observation since the use of Neosaldina (a medication consisting of Dypirone, isometheptene and caffeine), for example, was strongly encouraged in television ads during the present study, with its use corresponding to $17 \%$ of the analgesics sold in Brazil in $2011^{3,4}$.

Dipyrone, in turn, occupied second place, followed by Paracetamol. The less used analgesics varied according to type of headache. In agreement with the present data, in Brazil, according to Corrado et al. ${ }^{12}$, pure Dipyrone and its combinations seem to be the medications most involved in the development of $\mathrm{MOH}$, since they are the analgesics of choice for the management of headache in the Brazilian population, with $31.8 \%$ of the market, followed by Paracetamol (29.7\%) and Aspirin (27.1\%). However, there are no conclusive studies confirming this result.

In Colombia, Martha et al. ${ }^{27}$ reported that the medications most involved in the onset of $\mathrm{MOH}$ were simple analgesics, triptans, ergot derivatives (especially ergotamine), opioids and a combination of the latter.

In a cohort study conducted on 216 patients, Zeeber et al. ${ }^{28}$ reported that most subjects (46\%) combined different types of analgesics, $29 \%$ consumed only simple analgesics, $20 \%$ took triptans, $6 \%$ opioids, and $4 \%$ ergotamine. Thus, we conclude that both the type of medication involved and the frequency of its use vary considerably among different countries ${ }^{29}$.

Since our service receives patients referred by doctors of the primary and secondary care networks who have already attempted to treat headache, $55 \%$ of the patients reported that they used medications prescribed by the doctor, while $34 \%$ performed self-medication. In a recent study conducted in the municipality of Santa Maria, State of Rio Grande do Sul, $76.1 \%$ of the subjects interviewed who used medication performed self-medication and only $23.9 \%$ took medication prescribed by a doctor ${ }^{30}$. In the cited study, headache was described as the main complaint motivating self-medication, with analgesics, including antipyretics and non steroidal anti-inflammatory drugs, being the major drug group used ${ }^{30}$.

Regarding the impact of headache on the patients, in all diagnoses made, most subjects attributed a score of 9 or 10 to the interference of headache with their work and leisure activities without the use of analgesics. When these patients took medications, the scores fell substantially to values between 3 and 8 , 
demonstrating a significant improvement in the execution of daily activities. On this basis, if, on the one hand, the excessive use of medication can lead to $\mathrm{MOH}$, on the other, its regular use improves the quality of life of the patients, a fact that can be accepted as the main motive of continued abuse of analgesics.

Some studies have also reported impairment of daily patient activities in the presence of pain, with consequent very high social costs ${ }^{31,32}$.

The present study showed that the prevalence of migraine and $\mathrm{MOH}$ was similar at the tertiary care level compared to other studies, although in our service there was a higher frequency of $\mathrm{MOH}$ among men than among women. On the other hand, there were discrepancies regarding the prevalence of TTH in specialized clinics.

In conclusion, in our service, $\mathrm{MOH}$, the second most predominant headache, was more prevalent among men, suggesting negligence and a delay in seeking specialized care compared to women.

The analgesics most frequently used during the crises were Dipyrone compounds including Neosaldina', indicating a strong influence of the media on the choice of symptomatic medication. This observation should serve as an alert to the governmental agencies that evaluate the appropriateness of this advertising in the media in general. However, according to the patients, the effectiveness in controlling the crises was also an important determinant in the choice of medication, with the drugs being used at the onset of pain or in the presence of very strong pain.

The patients reported that the use of symptomatic medications promoted a significant reduction of the interference of headache with their activities, although the patients did not perceive the side effects of the drugs, i.e., the bad side of abuse. These observations suggest that this attitude motivates the perpetuation of this habit.

$\mathrm{MOH}$ is the most prevalent secondary headache observed in specialized clinics and is still insufficiently investigated. New studies may improve the diagnostic and therapeutic approach to this type of headache, thus contributing to its prevention, to a reduction of costs and of analgesic use and to an improvement of quality of life.

\section{References}

1. Ferri-de-Barros JE, Nitrini R. [Which patients does the neurologist assist? Basis for a curriculum in neurology]. Arq Neuropsiquiatr. 1996;54(4):637-44. Portuguese. http://dx.doi.org/10.1590/S0004-282X1996000400013

2. Headache Classification Subcommittee of the International Headache Society. The international classification of headache disorders: 2nd edition. Cephalalgia. 2004;24(Suppl s1)1:9-160.

3. Dezem V. Brasil lidera emergentes no consumo de analgésico. Valor Econômico. 31 mai. 2011 [cited 2014 Sept 14]. Available from http:// www.valoronline.com.br/impresso/empresas/102/434475/brasillidera-emergentes-no-consumo-de-analgesico

4. Fraga Júnior PJ. As curvas da dor e do sorriso: comercial de analgésico substitui indicações médicas por valores do consumo e do trabalho para vender mais drágeas. Dito Efeito. 2013;5(4):1-11.

5. Bigal ME, Serrano D, Buse D, Scher A, Stewart WF, Lipton RB. Acute migraine medications and evolution from episodic to chronic migraine: a longitudinal population-based study. Headache. 2008;48(8):1157-68. http://dx.doi.org/10.1111/j.1526-4610.2008.01217.x

6. Solomon S, Lipton RB, Newman LC. Evaluation of chronic daily headache: comparison to criteria for chronic tension-type headache. Cephalalgia. 1992;12(6):365-83. http://dx.doi.org/10.1111/j.1468-2982.1992.00365.x

7. Pfaffenrath V, Isler H. Evaluation of the nosology of chronic tension-type headache. Cephalalgia. 1993;13(2 Suppl 12):60-2.

8. Associação da Indústria Farmacêutica de Pesquisa. Guia 2013. 4a ed. São Paulo: Interfarma; 2013 [cited 2014 Sept 4]. p. 1-106. Available from: http://www.interfarma.org.br/uploads/biblioteca/33guia-interfarma-2013-site.pdf

9. Alves Filho F, Tarantino M. As armadilhas dos analgésicos. Isto É. 2011 [cited 2014 Sept 4];(2194). Available from: http://www.istoe. com.br/reportagens/179642_AS+ARMADILHAS+DOS+ANALGESICO S? path $I$ magens $=\&$ path $=\&$ actual $\mid$ rea $=$ internalPage

10. Painel Internacional de Avaliação da Segurança da Dipirona; 2001 Jul 3-4; Brasília, DF. Brasília, DF: ANVISA; 2001 [cited 2012 Sept 8]. Available from: http:www.anvisa.gov.br/divulga/informes/relatoriodipirona2.pdf
11. Diener HC, Limmroth V. Medication-overuse headache: a worldwide problem. Lancet Neurol. 2004;3(8):475-83. http://dx.doi.org/10.1016/S1474-4422(04)00824-5

12. Limmroth V, Katsarava Z. Medication overuse headache. Curr Opin Neurol. 2004;17(3):301-6. http://dx.doi.org/10.1097/00019052-200406000-00011

13. Lu SR, Fuh JL, Chen WT, Juang KD, Wang SJ. Chronic daily headache in Taipei, Taiwan: prevalence, follow-up and outcome predictors. Cephalalgia. 2001;21(10):980-6. http://dx.doi.org/10.1046/j.1468-2982.2001.00294.x

14. Zwart JA, Dyb G, Hagen K, Svebak S, Holmen J. Analgesic use: a predictor of chronic pain and medication overuse headache: the Head-HUNT Study. Neurology. 2003;61(2):160-4. http://dx.doi.org/10.1212/01.WNL.0000069924.69078.8D

15. Wang SJ, Fuh JL, Lu SR, Liu CY, Hsu LC, Wang PN et al. Chronic daily headache in Chinese elderly: prevalence, risk factors, and biannual follow-up. Neurology. 2000;54(2):314-9. http://dx.doi.org/10.1212/WNL.54.2.314

16. Felício AD, Bichuetti DB, Santos WAC, Godeiro Junior CO, Marin LF, Carvalho DS. Epidemiology of primary and secondary headaches in a Brazilian tertiary-care center. Arq Neuropsiquiatr. 2006;64(1):41-4. http://dx.doi.org/10.1590/S0004-282X2006000100009

17. Rasmussen BK. Migraine and tension-type headache in a general population: precipitating factors, female hormones, sleep pattern and relation to lifestyle. Pain. 1993;53(1):65-72. http://dx.doi.org/10.1016/0304-3959(93)90057-V

18. Silva Junior AA, Tavares RM, Lara RP, Faleiros BE, Gomez RS, Teixeira AL. Frequency of types of headache in the tertiary care center of the Hospital das Clínicas of the Universidade Federal de Minas Gerais, MG, Brazil. Rev Assoc Med Bras. 2012;58(6):709-13. http://dx.doi.org/10.1590/S0104-42302012000600017

19. Silva-Júnior AA, Faleiros BE, Santos TM, Gómez RS, Teixeira AL. Relative frequency of headache types: a longitudinal study in the tertiary care. Arq Neuropsiquiatr. 2010;68(6):878-81. http://dx.doi.org/10.1590/S0004-282X2010000600009

20. Lipton RB, Bigal ME. Migraine: epidemiology, impact, and risk factors for progression. Headache. 2005;45(1 Suppl 1):S3-13. http://dx.doi.org/10.1111/j.1526-4610.2005.4501001.x 
21. Silva-Júnior AA. Comparação das características das cefaleias primárias na comunidade com as de um centro terciário de atendimento [thesis]. Belo Horizonte: Universidade Federal de Minas Gerais; 2011

22. Diener HC, Dahlöf CGH. Headache associated with chronic use of substances. In: Oleson J, Tfelt-Hansen P, Welch K MA, editors. The headaches. 2nd ed. Philadelphia: Lippincott;1999. p. 871-8.

23. Stovner LJ, Hagen K, Jensen R, Katsarava Z, Lipton $\mathrm{R}$, Scher Al et al. The global burden of headache: a documentation of headache prevalence and disability worldwide. Cephalalgia. 2007;27(3):193-210. http://dx.doi.org/10.1111/j.1468-2982.2007.01288.x

24. Vasconcelos LPB, Stancioli FG, Leal JC, Costa EAC, Silva Júnior AA, Gomez RS et al. Cefaleias em serviço especializado. Migrâneas Cefaleias. 2006;9(1):4-7.

25. Krymchantowski AV, Moreira Filho PF. Cefaléia crônica diária primária: apresentação clínica. Arq Neuropsiquiatr. 2000;58(2B):437-51. http://dx.doi.org/10.1590/S0004-282X2000000300008

26. Irimia P, Palma JA, Fernandez-Torron R, Martinez-Vila E. Refractory migraine in a headache clinic population. BMC Neurol. 2011;11(1):94. http://dx.doi.org/10.1186/1471-2377-11-94
27. Alvarez S MR, García G RG, Silva S FA. Cefalea por uso excesivo de medicamentos: implicaciones clinicas y terapéuticas. Acta Neurol Colomb. 2010;26(4):195-291.

28. Zeeberg P, Olesen J, Jensen R. Probable medication-overuse headache: the effect of a 2-month drug-free period. Neurology. 2006;66(12):1894-8. http://dx.doi.org/10.1212/01.wnl.0000217914.30994.bd

29. Oliveira MF, Speciali JG. Cefaleia crônica diária: conceitos e tratamentos. Medicina. 2002;35(4):455-63.

30. Vilarino JF, Soares IC, Silveira CM, Rodel PP, Bortoli R, Lemos RR. [Self-medication profile in a city in South Brazil]. Rev Saúde Pública. 1998;32(1):43-9. Portuguese. http://dx.doi.org/10.1590/S0034-89101998000100006

31. Vincent M, Rodrigues AJ, Oliveira GV, Souza KF, Doi LM, Rocha MB et al. [Prevalence and indirect costs of headache in a Brazilian Company]. Arq Neuropsiquiatr. 1998;56(4):734-43. Portuguese. http://dx.doi.org/10.1590/S0004-282X1998000500006

32. Bigal ME, Bigal JM, Betti M, Bordini CA, Speciali JG. Evaluation of the impact of migraine and episodic tension-type headache on the quality of life and performance of a university student population. Headache. 2001;41(7):710-9. http://dx.doi.org/10.1046/j.1526-4610.2001.041007710.x 